\title{
Heavy Metal (Pb and Cd) Removal Potential of Cactus Powder in Ground Water at Adigrat
}

\author{
Tessema Derbe Hailegebrial
}

Department of Chemistry, Adigrat University, Ethiopia

Copyright $\bigcirc 2017$ by authors, all rights reserved. Authors agree that this article remains permanently open access under the terms of the Creative Commons Attribution License 4.0 International License

\begin{abstract}
The main objective of this study is to investigate the heavy metals $(\mathrm{Pb}$ and $\mathrm{Cd})$ removal capability of cactus powder from ground water using FAAS adsorption techniques by considering the influence of contact time, adsorbent dose and temperature. The results revealed that adsorption of $\mathrm{Pb}$ and $\mathrm{Cd}$ ions increased as the dose of adsorbent increased at a certain limits. The heavy metal removal capability of cactus powder is affected by the present of $\mathrm{NaCl}$ salt. The heavy metal removal capability of cactus powder decreased from $65 \%$ up to $7 \%$ for $\mathrm{Pb}$, and from $70 \%$ up to $14 \%$ for $\mathrm{Cd}$ as the dose of $\mathrm{NaCl}$ increased from $1 \mathrm{~g}$ to $5 \mathrm{~g}$. This is due to the formation of outer sphere complex with the $\mathrm{NaCl}$ salt which screening the functional group of cactus powder from heavy metals. The heavy metal removal capability of cactus powder also increased with contact time. The adsorption rate initially increased from $20 \%$ to $58 \%$ for $\mathrm{Pb}$ ion, and $17 \%$ to $43 \%$ for $\mathrm{Cd}$ ion when the contact time increased from 30-120 min. After $120 \mathrm{~min}$, there was no significant change in heavy metal removal of both $\mathrm{Pb}$ and $\mathrm{Cd}$ ions. This might be due to end point at which adsorption phase reached at equilibrium. The percentage removal of $\mathrm{Pb}$ by cactus powder decreased from $65.05 \%$ to $29 \%$ as the temperature increased from $25^{\circ} \mathrm{C}$ to $150^{\circ} \mathrm{C}$. In similar condition, the percentage removal of $\mathrm{Cd}$ by cactus powder also decreased from $43 \%$ to $31 \%$ as the temperature increased from $25^{\circ} \mathrm{C}$ to $150^{\circ} \mathrm{C}$. This decrement in percentage removal of both $\mathrm{Pb}$ and $\mathrm{Cd}$ ions with increase temperature is due to the weak binding interaction between the active site of cactus powder and $(\mathrm{Pb}, \mathrm{Cd})$ ions which support physicosorption process.
\end{abstract}

Keywords Cactus Powder, Heavy Metal, Adsorbent, Adsorbate, Dose and Active Site

\section{Introduction}

Heavy metals are the most hazardous and harmful metals even if they present as traces quantities, since they are accumulated in the tissue of living organisms[1, 2]. Heavy metals include lead, silver, mercury, copper, nickel, chromium, zinc, cadmium and tin have a detrimental health effects on human being and animals [2]. Many toxic heavy metals like $\mathrm{Pb}^{+2}, \mathrm{Cu}^{+2}, \mathrm{Fe}^{+3}$ and $\mathrm{Cr}^{+3}$ have been discharged into the environment as industrial wastes, causing serious soil and water pollution which leads numerous diseases and disorders [1-4]. Every day, there are many chemicals discharged directly and indirectly into water bodies without further treatment for elimination of harmful compounds (Salim et al., 2008). These heavy metals contamination in ecosystems pose a major environmental problem worldwide [2-5]. They are toxic environmental pollutants which arise from anthropogenic activities such as metallurgical process, sewage sludge treatment, warfare, military training, waste disposal sites, fertilizers and pesticides [4-6].

Contamination and subsequent pollution of the environment by trace metals have become an issue of global level due to their sources, widespread distribution and multiple effects on the ecosystem $[3,6]$. Once they inter in living organism, they inhibit transpiration and photosynthesis of plants $[3,4,6]$. They disturb carbohydrate metabolism, and they drive the secondary stresses like nutrition and oxidative stresses $[2,5,6]$. They affect the normal function of liver, cardiovascular and central nervous systems, muscle, heart and kidney [5-7]. A widespread of heavy metal such as $\mathrm{Pb}$ in water is hazardous to the environment and human health, and their discharge into surface water is one of the great suspicions throughout the world $[2,3]$. Therefore, they must be removed to certain levels to meet discharge requirements [2.3].

Lead $(\mathbf{P b}): \mathrm{Pb}$ is one of the most toxic metal which is very persistent pollutant in the environment $[1,5,7,8]$. It is found in trace amount in rock, soil, water, plant, animals and air [2, $8,9]$. Its chemical reactivity is a function of the combined properties of the metal and the associated ligands, and hence resulted in different biological effects $[2,10]$. Inorganic compounds of lead such as halides, oxides, sulfites, sulfate; carbonate and chromate are mostly exposed to humans being $[2,5,11]$. Lead also binds to the thiol $\left(\mathrm{SH}^{-}\right)$chemical group in the enzymes and consequently reduces the body's ability to synthesize enzymes which is necessary for respiration and 
digestion $[5,11]$.

The toxicity of lead influences brain, heart, kidney, liver, central nervous system, and pancreas. Moreover, diseases like bone pain, dizziness, drowsiness, fatigue, headaches and hypertension are the signs and the symptoms of the exposure of $\mathrm{Pb}[1,5,6]$.

Cadmium (Cd): Cd (II) is the most toxic and hazardous metal ion for living organism and its allowable limit in drinking water must be $0.005 \mathrm{mg} / \mathrm{L}$ [1]. It occurs naturally in ores together with zinc, lead and copper [1-3]. Natural and anthropogenic sources of cadmium, including industrial emission and the application of fertilizer and sewage sludge to farm land, may lead to contamination of soil and water [1, 2]. Smoking of cigarette also has a major source of cadmium exposure which causes significant increases in blood cadmium (B-Cd) levels $[1,11]$. Cadmium is a cumulative toxicant and carcinogenic that affects kidney; disturbs bone metabolism and deforms reproductive tract as well as endocrine system [2, 12]. Espousing of cadmium causes skeletal demineralization, probably leading to increases in bone fragility and risk of fractures [1, 2, 11]. It also causes disturbances, lung insufficiency, bone lesions, cancers, weight loss and hypertension [1]. As a result of the above impacts, removal and eliminating of Cd (II) in the polluted water has become a vital mission and essential environmental goal in this work.

By considering the impact of heavy metals on human health, recently a numerous heavy metal removing methods are developed such as ion exchange, precipitation, ultrafiltration, reverse osmosis and electrodialysis $[1,6,9]$. Besides, many natural products have the ability to bind heavy metal by replacement of hydrogen ions for metal ions in solution or by donation of an electron pair from these groups to form complexes with the metal ions in solution [1]. Many researchers also reported the relationship between the presence of various functional groups and their complexation with heavy metals during biosorption process (Tarley and Arruda, 2004).

Plant based materials are very attractive for many accessibility criteria. This is because they usually are renewable, abundant, environmentally friendly, adaptable and biodegradable. Therefore, this study is designed to investigate heavy metal $(\mathrm{Pb}$ and $\mathrm{Cd})$ removal capability of cactus powder using FAAS adsorption method.

\section{Method and Material}

\subsection{Description of Study Area}

The present study is conducted in Adigrat University, in northern region of Ethiopia. Adigrat is a city and separate woreda that found in Tigray Region of Ethiopia. It is located in the eastern zone of Tigray around $900 \mathrm{~km}$ far from the capital city of Ethiopia with longitude $14^{\circ} 16^{\prime} \mathrm{N} 39^{\circ} 27^{\prime} \mathrm{E}$ coordinates and latitude $14^{\circ} 16^{\prime} \mathrm{N} 39^{\circ} 27^{\prime} \mathrm{E}$ with an elevation of 2457 meters above sea level. Adigrat is endowed with cactus plant which is harvested once in a year. The largest pharmaceutical manufacturing in Ethiopia, 'Addis Pharmaceuticals Factory SC', is also located in Adigrat. The laboratory is performed at Arba Minch University and at Ezana milling industry (Mekelle).

\subsection{Equipment and Instrument}

Atomic absorption spectroscopy (buck scientific, model 210VGP FAAS) equipped with deuterium arc back ground correctors and hollow cathode lamps with air-acetylene flame was used for the analysis of the heavy metals $\mathrm{Cd}$ and $\mathrm{Pb}$. Water bath was used to maintain temperature due to unavailability of Thermostat.

\subsection{Reagent and Chemical}

Stock standard solutions containing $1000 \mathrm{ppm}$ of the metals $\mathrm{Cd}$ and $\mathrm{Pb}$ were used for preparation of standards. Deionized water was used for rinsing of the glassware, sample bottles and for dilution of the sample solution. $\mathrm{NaCl}$ salt was used to check the effect of ionic strength on heavy metal removal capability of cactus powder.

\subsection{Collection of Plant Samples}

Mature healthy and fresh leaves of cactus were collected from side of Adigrat town. The collected leaves were washed with distilled water and the leaves were cut in to small pieces. The tip egged and their thick epidermis was removed. The solid gel was dried at $80-90^{\circ} \mathrm{C}$ in electric oven. The dried plant materials were ground into powder form using pestle and mortar. Two ppm of a known concentration of heavy metal $\mathrm{Cd}$ and $\mathrm{Pb}$ was placed into six $100 \mathrm{~mL}$ round flasks. Different dosages of cactus $(1,2,3,4,5 \mathrm{~g})$ were added and were filled with deionised water up to the mark of the flask. The absorbance was measured using AAS with different temperature and contact time to see the effect of temperature and contact time on adsorption of heavy metals by cactus, respectively. The absorbance was compared in the present and in the absent of cactus powder. The percent of adsorption $(\%)$ heavy metals by cactus powder were calculated using the equations [1]:

$$
\% \text { adsorption }=\frac{C_{i}-C_{f} x 100}{C_{i}} \ldots \ldots \ldots \ldots . . . \text { equation }-1
$$

Where, $C_{i}$ and $C_{f}$ are the concentrations of the heavy metals in the absent of cactus and in the present of cactus, respectively.

The percentage removal (\%) of $\mathrm{Pb}$ and $\mathrm{Cd}$ metals at various contact time was also calculated using equation 2

$$
\text { \%removal }=\frac{C_{t_{o}}-C_{t} x 100}{C_{t_{o}}} \text {..........equqtion }-2
$$

Where, $\mathrm{C}_{\mathrm{to}}$ and $\mathrm{C}_{\mathrm{t}}$ are the concentrations of the $\mathrm{Ca}$ and $\mathrm{Mg}$ metals at initial and final time, respectively 


\subsection{Statistical Analysis}

After the results were obtained and recorded, the mean, standard deviation, regression and correlation factors, concentration and others were performed using data analysis packages such as Microsoft Excel 2007, Chemdraw ultr8.0,Gause view03 and originlab 8.1. All measurements were done in triplicate and the results were reported as average values $\pm \mathrm{SD}$.

\section{Result and Discussion}

\subsection{Instrument Calibration}

The calibration curves were plotted as a function of absorbance versus concentration of the standard solution. In this study, two calibration curves were plotted for the metals $\mathrm{Cd}$ and $\mathrm{Pb}$ as shown in Fig 1.
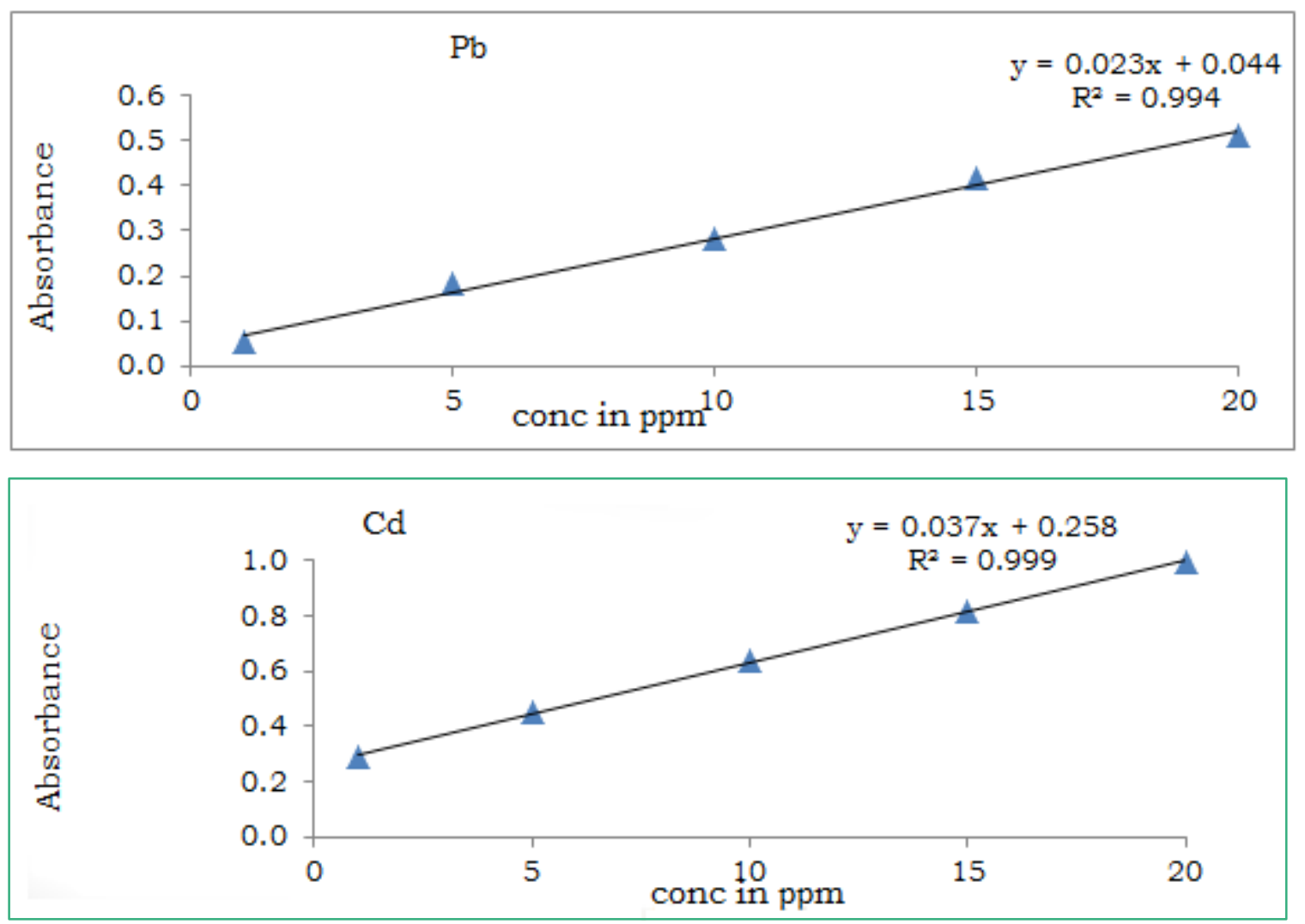

Figure 1. The calibration graphs of metal standard solution

Table 1. Effect of cactus dosage on removal of heavy metals at $2 \mathrm{ppm}$ initial concentration of both $\mathrm{Pb}$ and $\mathrm{Cd}$ metals

\begin{tabular}{|c|c|c|}
\hline Cactus Sample in gram & Concentration of Pb in ppm & Concentration of Cd in ppm \\
\hline 0.00 & $1.83 \pm 0.025$ & $2.09 \pm 0.004$ \\
\hline 1.00 & $0.64 \pm 0.007$ & $1.64 \pm 0.008$ \\
\hline 2.00 & $0.64 \pm 0.003$ & $1.70 \pm 0.011$ \\
\hline 3.00 & $0.63 \pm 0.001$ & $1.70 \pm 0.024$ \\
\hline 4.00 & $0.62 \pm 0.018$ & $1.67 \pm 0.015$ \\
\hline 5.00 & $0.63 \pm 0.016$ & $1.13 \pm 0.022$ \\
\hline
\end{tabular}




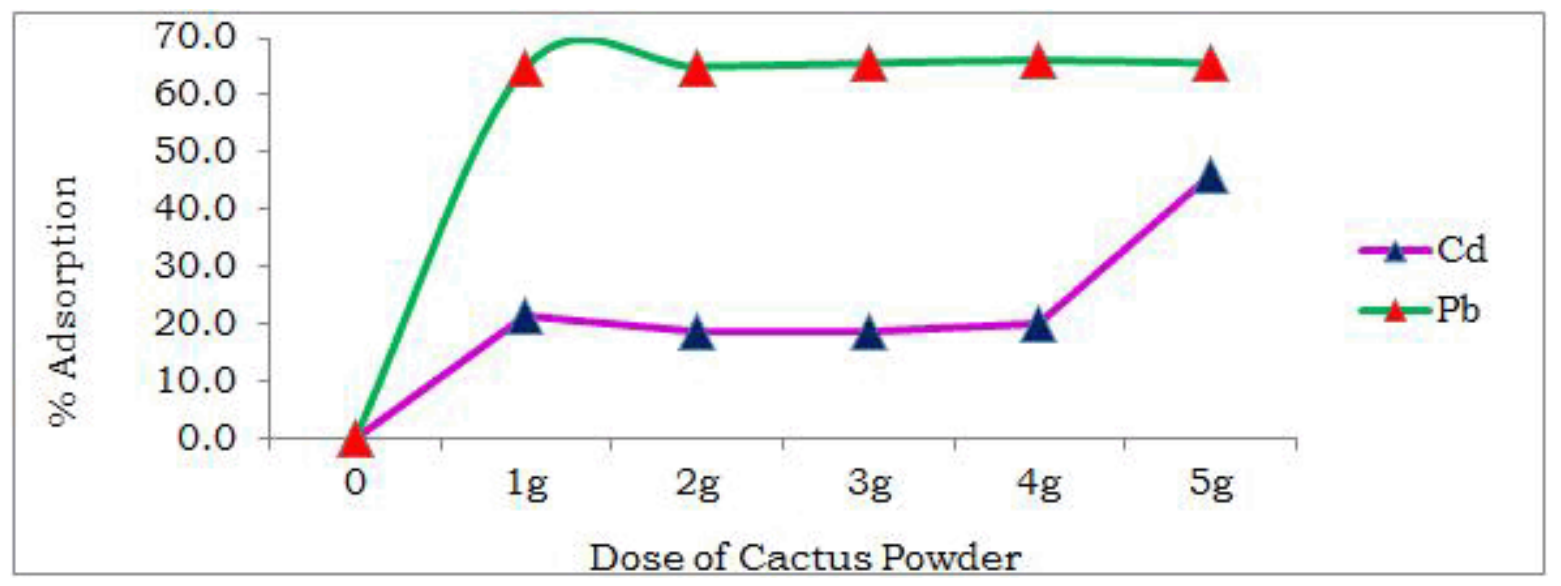

Figure 2. Effect of dosage of cactus powder on removal of $\mathrm{Pb}$ and $\mathrm{Cd}$ metals

\subsection{Effect of Cactus Dosage on Removal of Heavy Metals}

The effect of adsorbent dose on the adsorption of heavy metals by cactus powder has been investigated by employing different doses of cactus powder. As shown in Fig 2 and table 1 , the percentages removal of $\mathrm{Pb}$ and $\mathrm{Cd}$ ions increased with the increasing of absorbent doses. At the first $1 \mathrm{~g}$ cactus powder, the heavy metal removal capability of cactus powder increased significantly for both $\mathrm{Pb}$ and $\mathrm{Cd}$ ions from $0 \%$ to $21.5 \%$ for $\mathrm{Cd}$ ion, and from $0 \%$ to $65.02 \%$ for $\mathrm{Pb}$ ion. Once the water sample is activated, the percentage removal of $\mathrm{Cd}$ ion by cactus powder remains constant up to $4 \mathrm{~g}$ of cactus powder. After $4 \mathrm{~g}$, at $5 \mathrm{~g}$ of cactus powder, the removal efficiency increased rapidly from $20.09 \%$ to $45.9 \%$. This indicates that to remove $\mathrm{Cd}$ metal from water sample a minimum $5 \mathrm{~g}$ of cactus powder is required.

In similar way, when the cactus powder increased from $2 \mathrm{~g}$ to $4 \mathrm{~g}$, the percentage removal of $\mathrm{Pb}$ ion increased from $65.03 \%$ to $66.02 \%$, and slight decrement occurs at $5 \mathrm{~g}$ of cactus powder. Further increasing of the quantity of cactus powder did not show any significant change on the removal of $\mathrm{Pb}$ from water sample. This due to the fact that active site of the cactus powder already occupied by $\mathrm{Pb}$ ion, and the solution is reaches equilibrium between the $\mathrm{Pb}$ ion and the cactus powder.

In general, the percentage removal of $\mathrm{Pb}$ and $\mathrm{Cd}$ ions increased with the dosage of cactus powder. As increasing of adsorbent dose, heavy metal removal efficiency increased due to the increment of adsorption sites. However, an over optimal amount of cactus powder would cause the aggregated particles to re-disperse into the suspension and would reduces removal of heavy metals $[1,7]$.

\subsection{Effect of NaCl Salt on Heavy Metal Removal of Cactus Powder}

The effect of ionic strength on heavy metal removal capability of cactus powder is determined by using table salts. As shown in Fig 3, the removal of $\mathrm{Pb}$ and $\mathrm{Cd}$ ions are decreased with increasing of $\mathrm{NaCl}$ salt. For $\mathrm{Pb}$ metal, the removal capability of cactus powder decreased from $65 \%$ up to $7 \%$, and for $\mathrm{Cd}$ metal, decreased from $70 \%$ up to $14 \%$ as the dose of $\mathrm{NaCl}$ increased from $1 \mathrm{~g}$ to $5 \mathrm{~g}$. The decrement in the removal of both $\mathrm{Pb}$ and $\mathrm{Cd}$ ions from water sample with increasing of $\mathrm{NaCl}$ is due to the formation of outer sphere complex with the $\mathrm{NaCl}$ salt.

Besides, $\mathrm{NaCl}$ salt has the capability of screening the functional group of cactus powder from trapping of heavy metals which results the charge repulsion (Fig 4). For low ionic strength, the removal of $\mathrm{Pb}$ and $\mathrm{Cd}$ cactus powder is higher. This is due to the fact that a little charge presents to screen the repulsive interaction between the heavy metal and the active site of cactus powder. But at high ionic strength the sodium ion can compete with $\mathrm{Pb}$ and $\mathrm{Cd}$ ions for the binding site of cactus powder, and reduce the heavy metal removal efficiency of cactus powder.

Generally, the decrement in percentage removal of $\mathrm{Pb}$ and $\mathrm{Cd}$ ions as the ionic strength increased is due electrostatic interaction between $\mathrm{Na}$ ion and active site to form stable complexes which inhibit interaction between $\mathrm{Pb}$ and $\mathrm{Cd}$ with active sites of the cactus powder (Fig 4). This may have been due to the competition of $\mathrm{Na}^{+}$acting as a bridge between adjacent strands of the active sites of cactus powder and thereby occluding attachment sites for the heavy metals. 


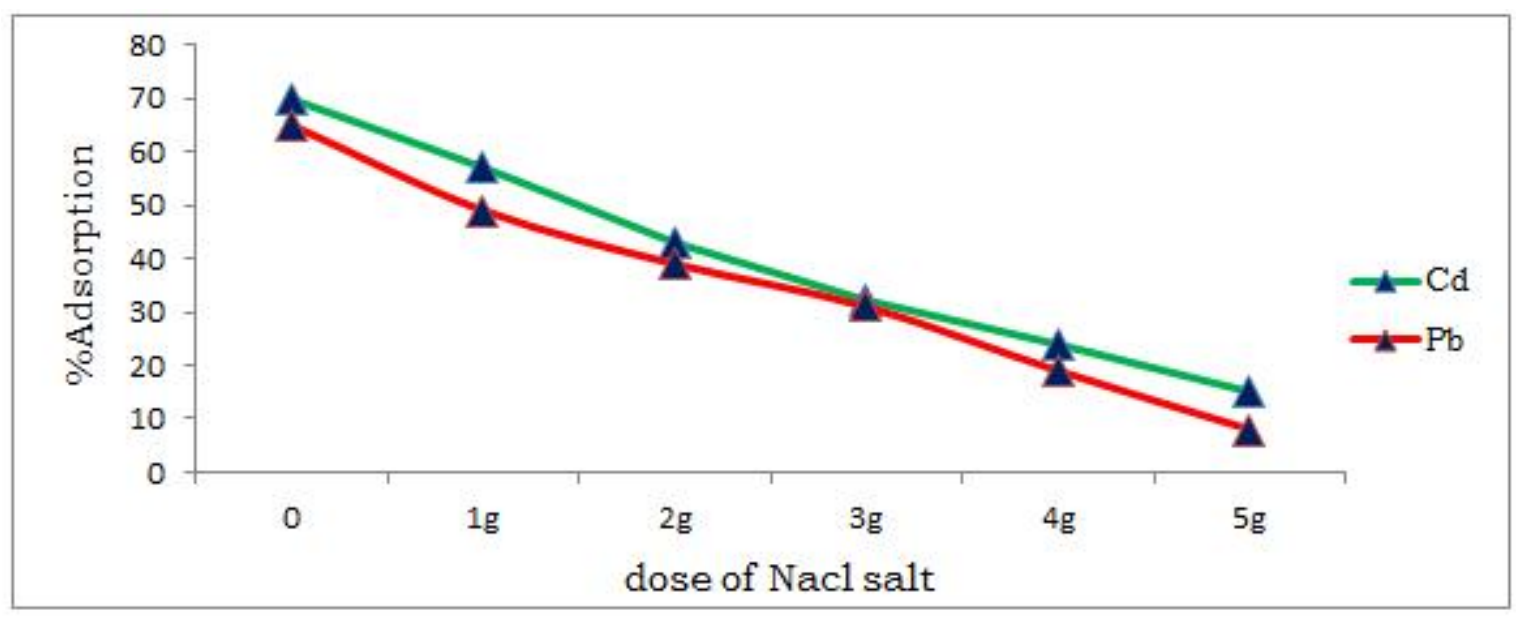

Figure 3. Effect of ionic strength on $\mathrm{Cd}$ and $\mathrm{Pb}$ ions removal using $1 \mathrm{~g}$ cactus powder with initial $2 \mathrm{ppm}$ of $\mathrm{Cd}$ and $\mathrm{Pb}$ at different dose of $\mathrm{NaCl}$ salt.

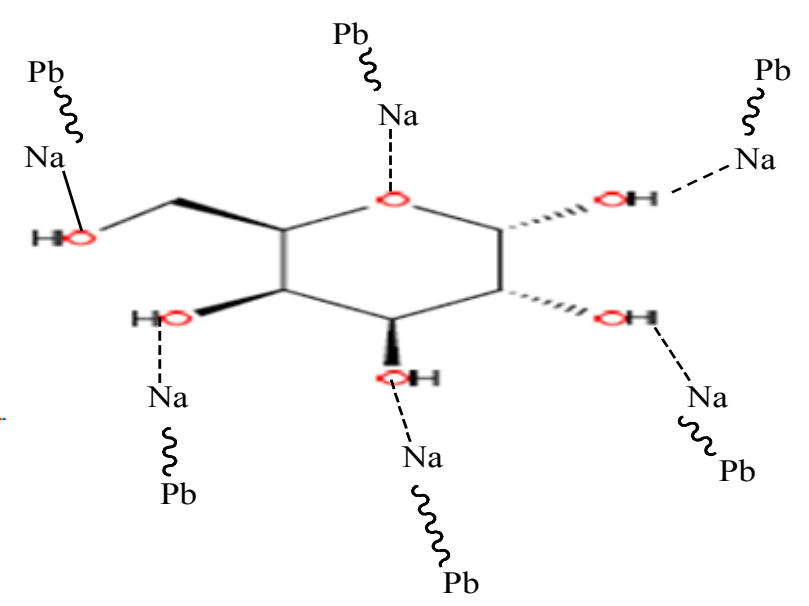

Galactose

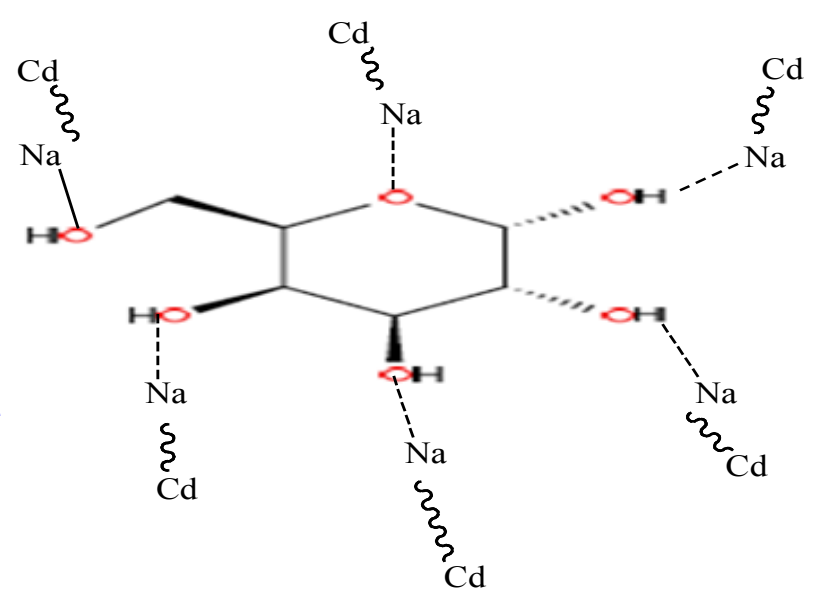

Galactose

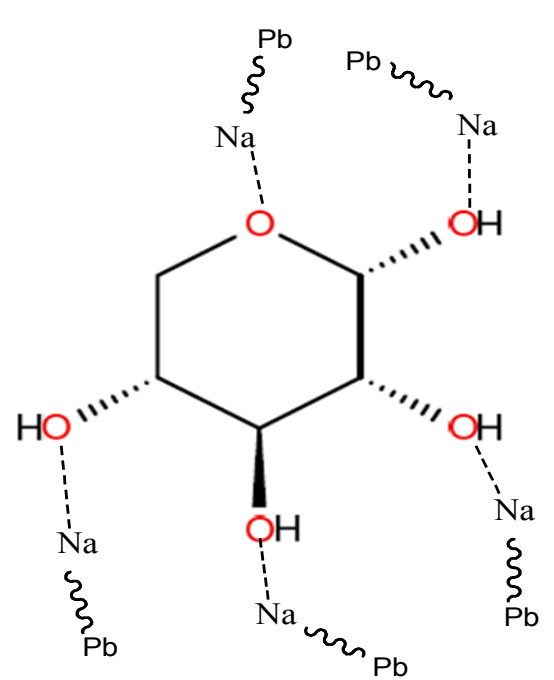

Xyloss

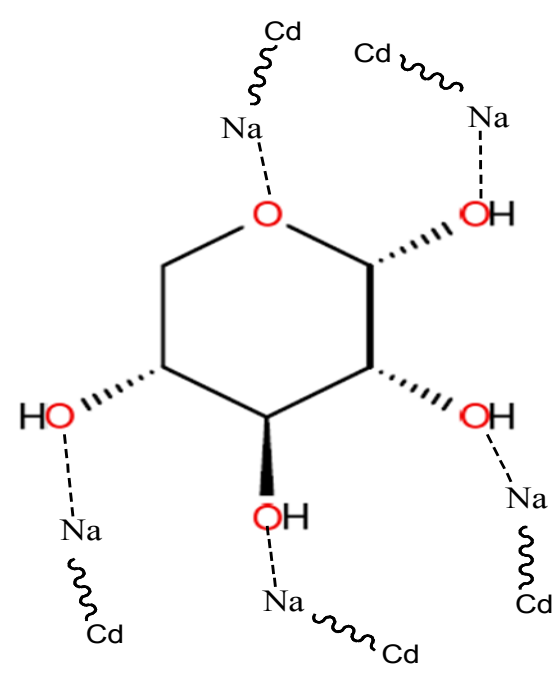

Xyloss 


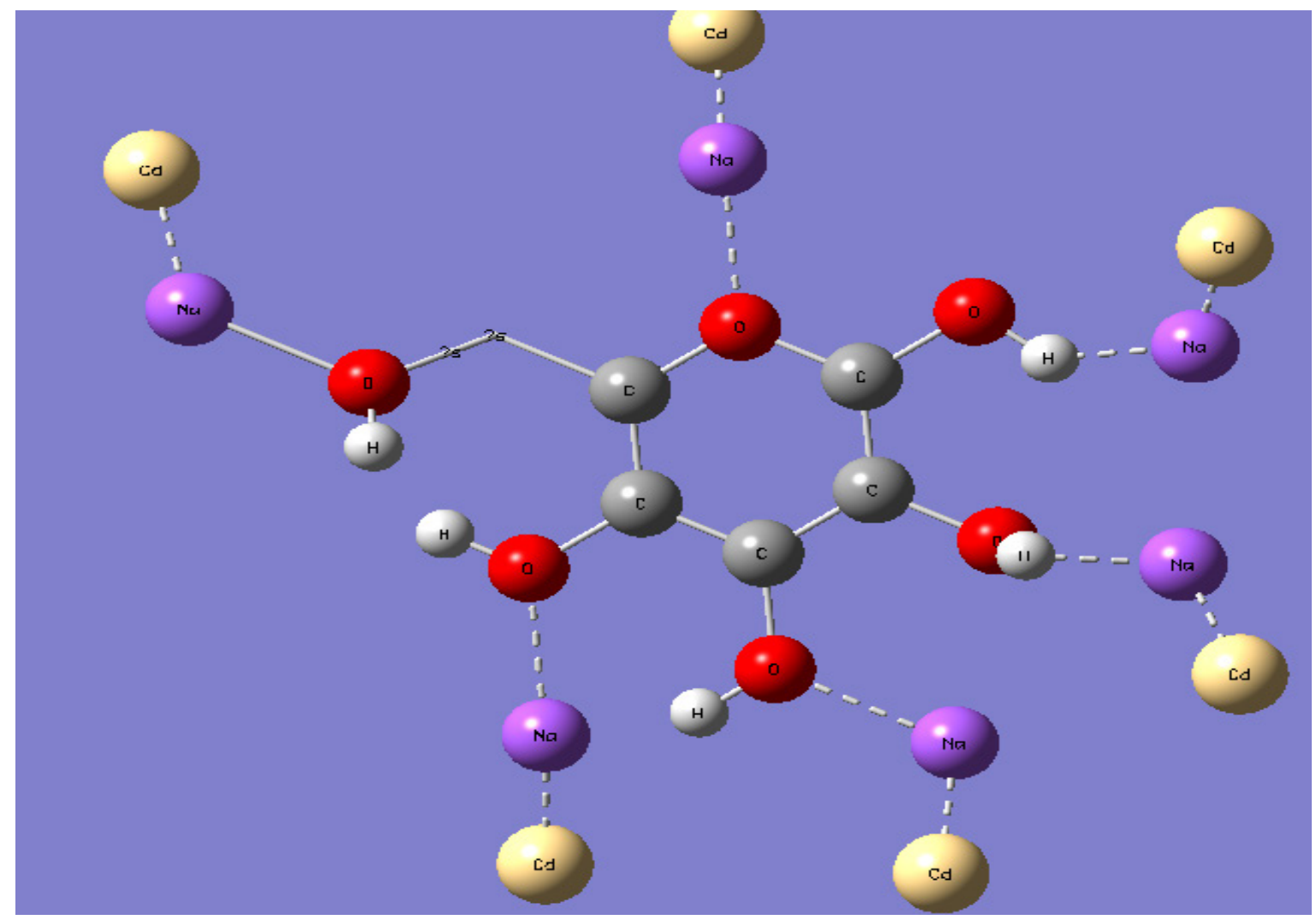

Figure 4. Effect of $\mathrm{NaCl}$ salt on removal of $\mathrm{Pb}$ and $\mathrm{Cd}$ metals

\section{4. Effect of Contact Time on Heavy Metal Removal of Cactus Powder}

As it can be seen from Fig 5, the removal capability of cactus powder for $\mathrm{Cd}$ and $\mathrm{Pb}$ metal ions are varied with contact time. The effect of contact time on heavy metal removal can be determined by phasing different time periods. The adsorption of $\mathrm{Cd}$ and $\mathrm{Pb}$ ions are increased with contact period of time at a certain limits. This leads the aggregation of heavy metal in the pore of active sites and start offering resistance to diffusion of aggregated heavy metals ions in the adsorbents $[12,13]$.

As it is shown in Fig 5, the adsorption rate initially increased from $20 \%$ to $58 \%$ for $\mathrm{Pb}$ ion, and $17 \%$ to $43 \%$ for $\mathrm{Cd}$ ion when the contact time increased from 30-120 min. After 120min, there is no significant change in heavy metal removal of both $\mathrm{Pb}$ and $\mathrm{Cd}$ ions. This might be due to end point at which adsorption phase reached to equilibrium.

In general, the adsorption of $\mathrm{Cd}$ and $\mathrm{Pb}$ ions are increased with contact period of time at a certain limits. This reason why as the contact time increased there is formation of stable complexes between the $\mathrm{Cd}$ and $\mathrm{Pb}$ metal ions with the active site of the cactus powder. Hence, the heavy metal removal capability of cactus powder increased with the contact time.

\subsection{Effect of Temperature on Heavy Metal Removal of Cactus Powder}

As shown in Fig 6, the percentage removal of $\mathrm{Pb}$ by cactus powder decreased from $65.05 \%$ to $29 \%$ as the temperature increased from $25{ }^{\circ} \mathrm{C}$ to $150{ }^{\circ} \mathrm{C}$. In similar way, the percentage removal of $\mathrm{Cd}$ by cactus powder also decreased from $43 \%$ to $31 \%$ as the temperature increased from $25^{\circ} \mathrm{C}$ to $150{ }^{\circ} \mathrm{C}$. This decrement in percentage removal of both $\mathrm{Pb}$ and $\mathrm{Cd}$ ions with increasing of temperature is due to the weak binding interaction between the active site of cactus powder and the metal ions which support physicosorption process [12]. The other probable reason for the decrement of heavy metal removal capability of cactus powder at higher temperature is due to a number of bonds in the active site (cactus powder) are weakened and broken which has flexible structure with the group of the active. Increasing in temperature may also cause the more pore expansion which may leads to leaching of heavy metal adsorbed on the adsorbent is physical adsorption[12].

The effects of temperature on heavy metal have been studied by many authors [7] by varying temperature and keeping other parameters constant such as neutral $\mathrm{pH}$, time, and adsorbent dose. The decrement in adsorption at high temperature might happen due to the fact that at high temperature, the heavy metal ions move with greater speed and less time of interaction in available active sites of the cactus powder $[1,8]$. 


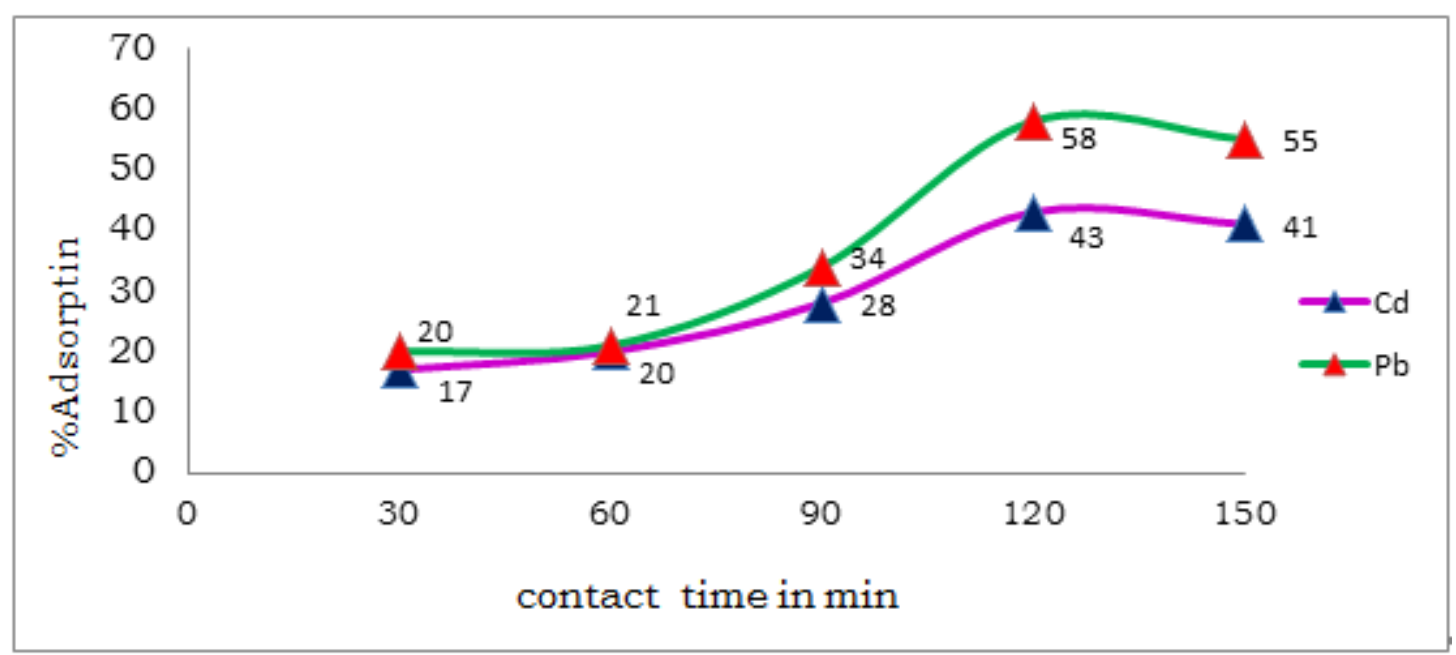

Figure 5. Effect of contact time on $\mathrm{Cd}$ and $\mathrm{Pb}$ ions removal using $1 \mathrm{~g}$ cactus powder at initial $2 \mathrm{ppm}$ of $\mathrm{Cd}$ and $\mathrm{Pb}$ at different time (min).

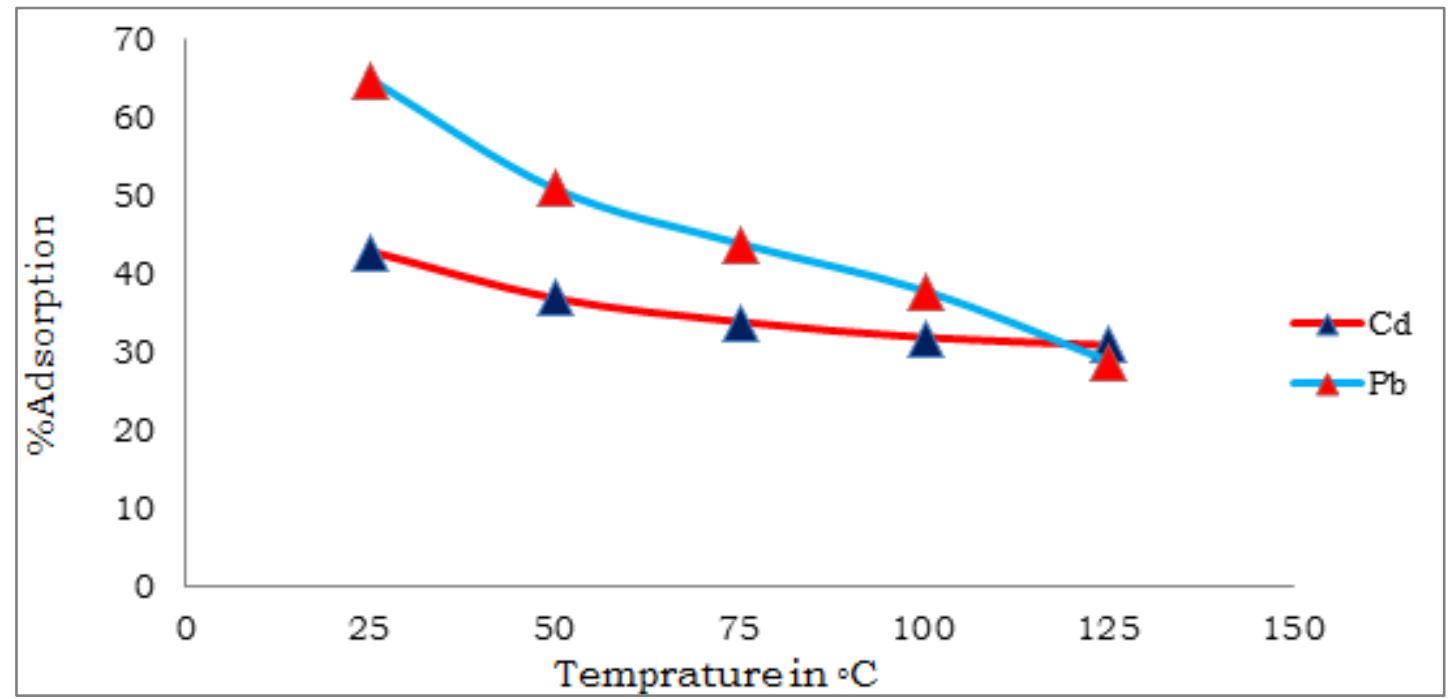

Figure 6. Effect of temperature on $\mathrm{Cd}$ and $\mathrm{Pb}$ ions removal using cactus powders at initial concentration of $2 \mathrm{ppm}$.

\subsection{Adsorption Isotherms}

\subsubsection{Frumkin Adsorption Isotherm}

The Frumkin isotherm is the earliest known relationship that describes the sorption that involves heterogeneous surface energy system $[9,12]$. The plot of \%AE against Log C (Fig. 7 A, B) shows a linear line which makes evident the adsorption of the heavy metals by cactus powder obeys the Frumkin isotherm (Saratha et al., 2009 and Patrick et al., 2006). The adsorption mode of $\mathrm{Pb}$ and $\mathrm{Cd}$ ions by cactus powder can be deduced from Frumkin adsorption Isotherm by plotting of \%AE against Log C (Fig 7 A, B). As shown in Fig. 7, the linear square regression co-efficient $R^{2}$ is 0.999 and 0.987 for $\mathrm{Pb}$ and $\mathrm{Cd}$ ion, respectively which is almost linear. This indicates that the sorption data were very best fit isotherm expression conform the monolayer coverage process between the cactus powder and heavy meals $\mathrm{Pb}$ and Cd ions.

The linear line in adsorption isotherm indicates the adsorption of both $\mathrm{Pb}$ and $\mathrm{Cd}$ in the active sites of the cactus powder is monolayer.

Conclusively, based on experimental studies, cactus powder has the capability to remove heavy metals from a given sample since it has a significant functional group that have been studied widely as sorbents for heavy metal cations by different scholars (Serguschenko, Kovalev et al. 2004; Nawirska 2005 [13]. The research team of Balaria and Schiewer (2008, 2009) showed spectroscopic (FTIR) evidence for the involvement of carboxylic acid functional groups in heavy metal binding [13]. These various functional groups of cactus plant are depicted in Fig 8 below. 


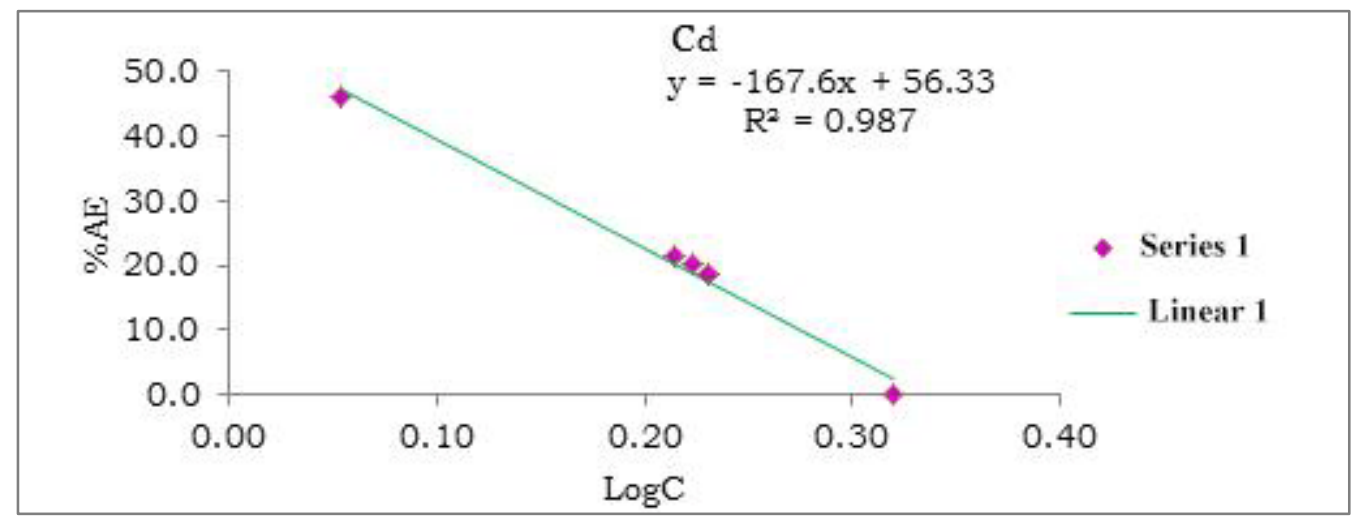

Figure 7 A. Frumkin Adsorption Isotherm $\mathrm{AE} \%$ versus $\mathrm{Log} C$ of $\mathrm{Cd}$ ion at $25^{\circ} \mathrm{C}$

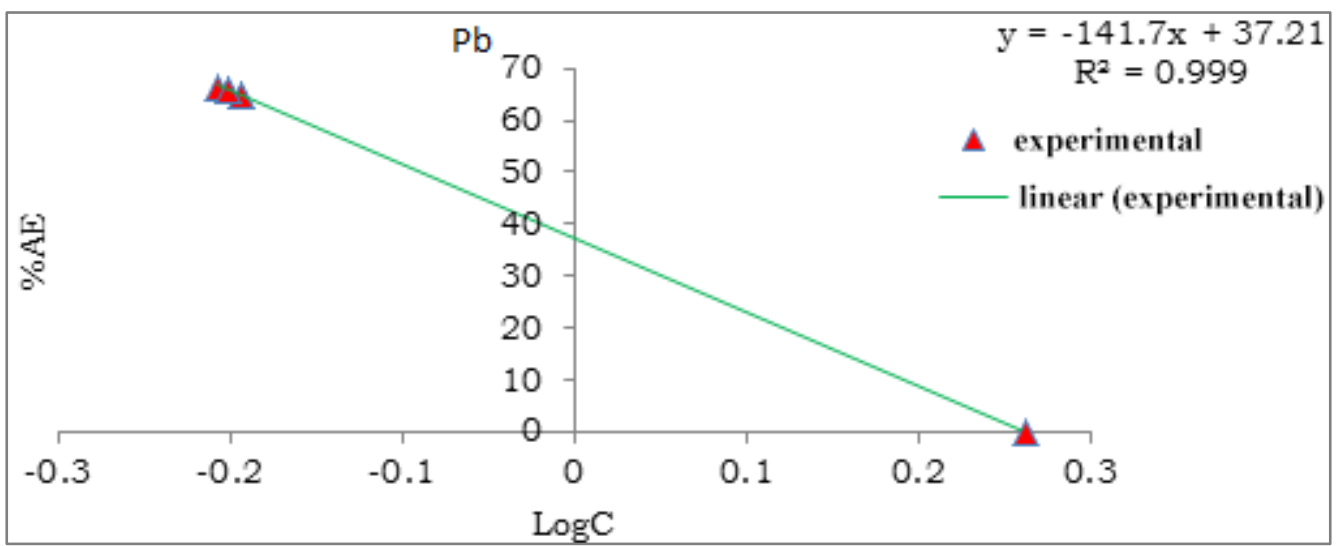

Figure 7 B. Frumkin Adsorption Isotherm $\mathrm{AE} \%$ versus $\log \mathrm{C}$ of $\mathrm{Pb}$ ion at $25^{\circ} \mathrm{C}$

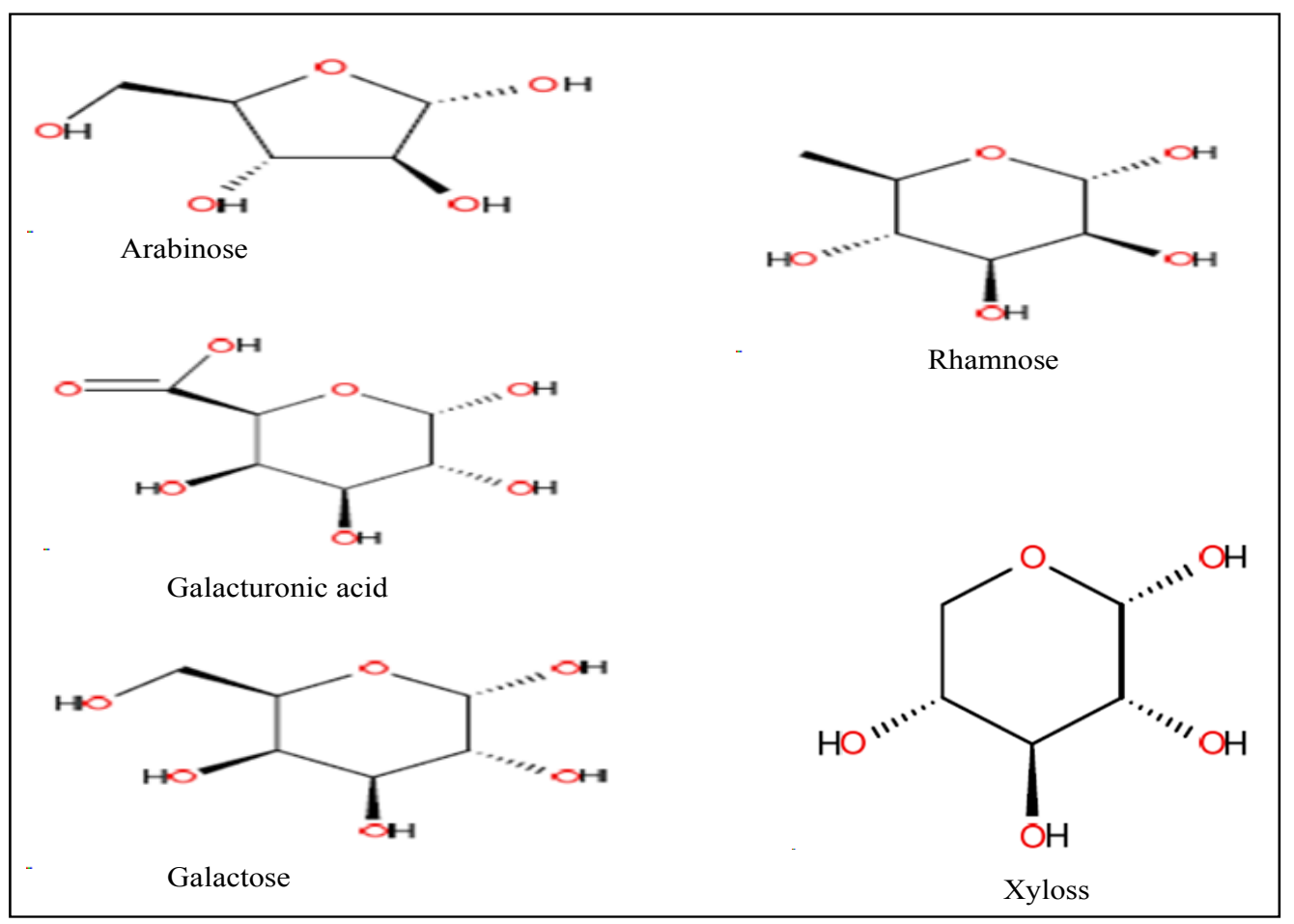

Figure 8. Schematic representations of functional groups that found in cactus plant (Dawn Iona Fox, 2011). 


\subsection{Mechanisms of Interaction between Cactus Powder and Heavy Metals}

As shown Fig 9, cactus powder has the capability of to bind heavy metals from water sample due to its functional groups. The heavy metal M, approaches towards the active site of cactus and trapped with it. This may leads the formation of complexes between the heavy metal $(\mathrm{Cd}$ and $\mathrm{Pb})$ and the active sites shown below.
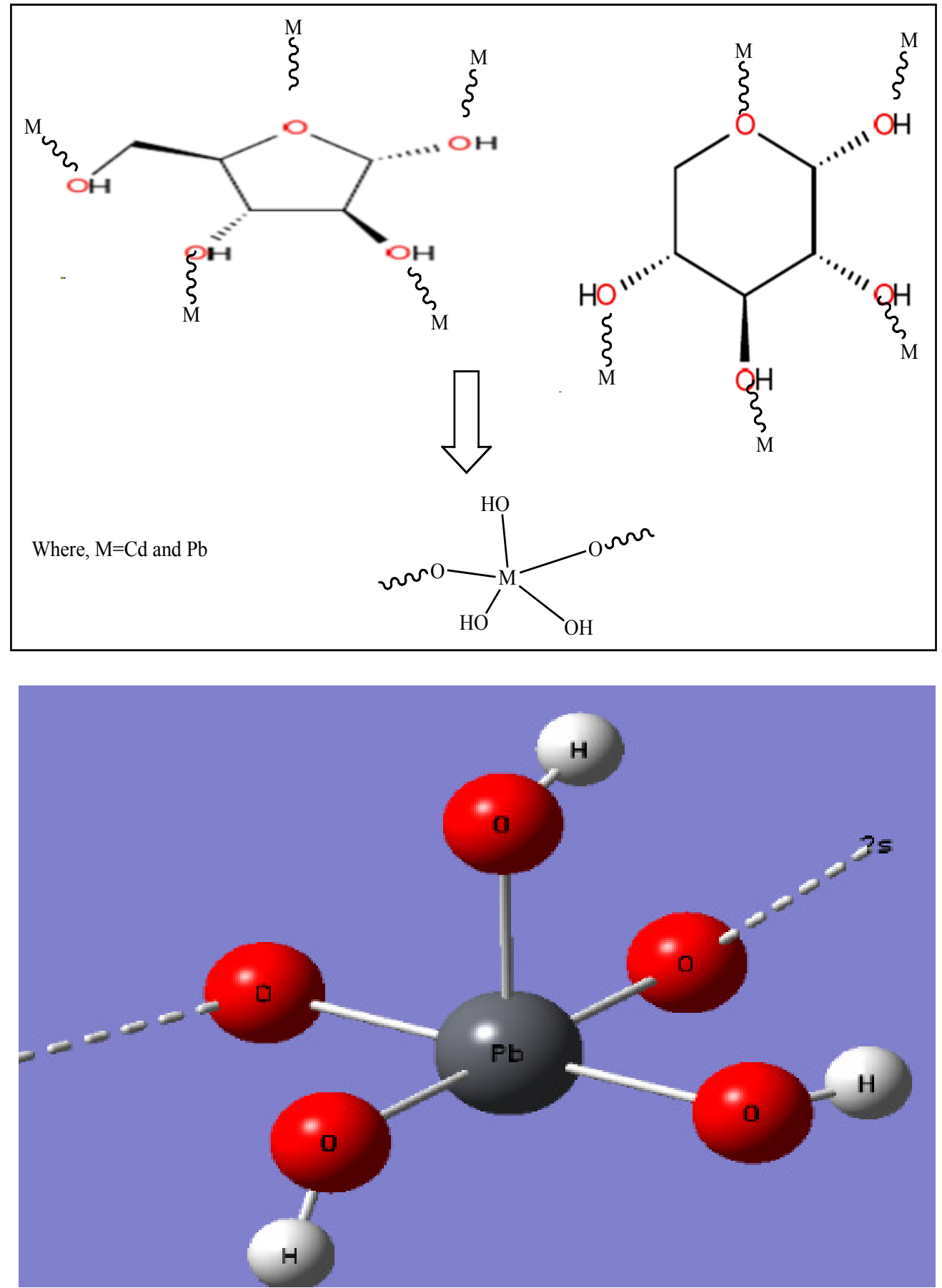


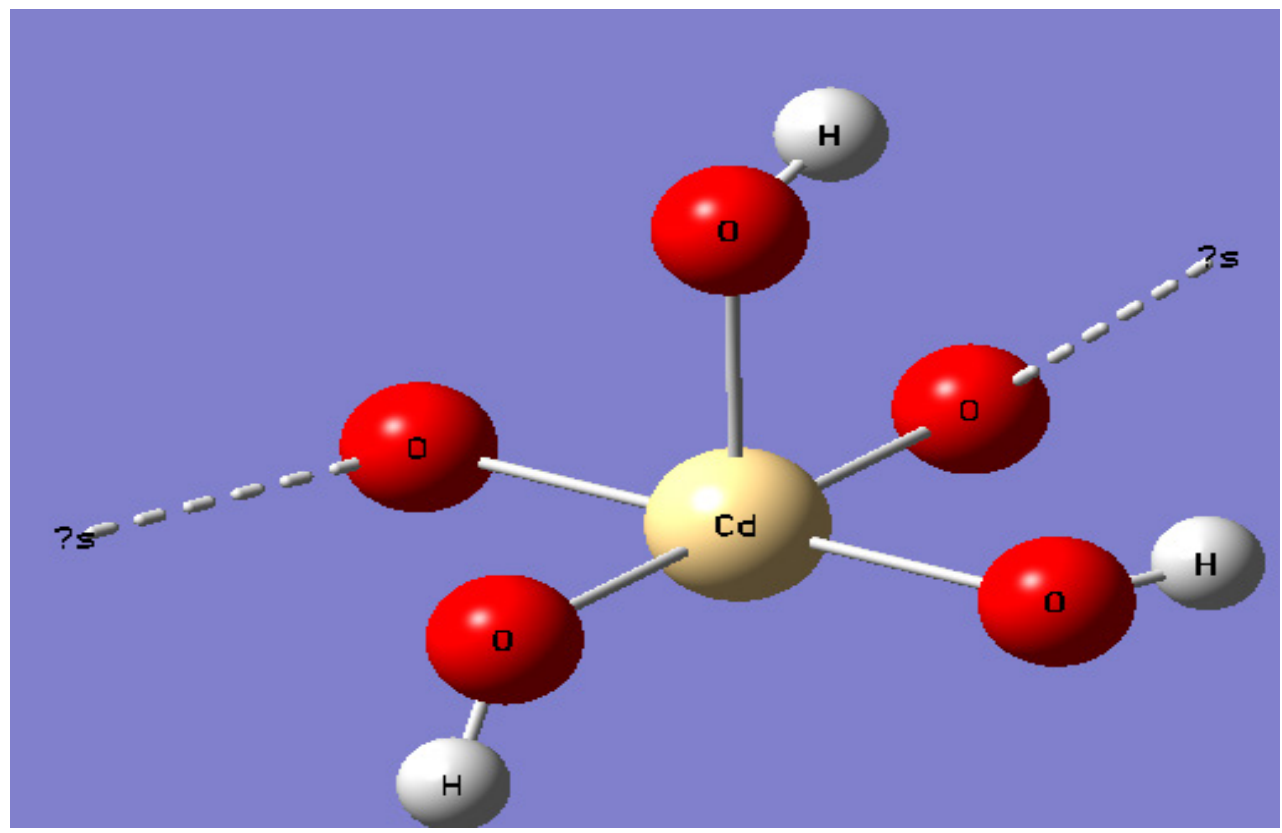

Figure 9. Mechanisms of interaction between cactus powder and heavy metal

In general, cactus powder has the capability to remove heavy metals $(\mathrm{Pb}$ and $\mathrm{Cd})$ from water sample due to the availability the above functional group as studied by various researchers Balaria and Schiewer (2008, 2009). Spectroscopic studies indicate the involvement of $\mathrm{CO}$ (carboxyl and carbonyl) and $\mathrm{OH}$ (hydroxyl) functional groups of the cactus powder leads in hydrogen bonding and donor-acceptor interactions with $\mathrm{Pb}$ and $\mathrm{Cd}$ metal ions to form coordinated compounds.

The present of plethora functional groups in cactus powder enable to trap metal ions from a given samples. This plant has received much attention many researchers because of the low cost and abundance; sustainability with the highest award for its affordability, reliability, ease of renewable, social acceptability, and environmental friendliness, which met the local environmental guidelines for heavy metals removal.

\section{Conclusions}

The study is conducted to evaluate heavy metal removal capability of cactus powder by viewing the influence of dosage, contact time, ionic strength and temperature. The result of this study raveled that Cactus powder is used as an agent for heavy metal $(\mathrm{Pb}$ and $\mathrm{Cd})$ removal from water sample. The heavy metal removal capability of cactus powder increased with its dose until a certain limits. The heavy metal removal capability of cactus powder decreased with increasing of temperature and ionic strength of $\mathrm{NaCl}$ salt. The linear Frumkin adsorption Isotherms indicates that the adsorption of $\mathrm{Pb}$ and $\mathrm{Cd}$ metal by cactus powder fits isotherm expression conform the monolayer coverage process between the cactus powder and heavy meals $\mathrm{Pb}$ and
Cd ions.

In general cactus is a natural product that has the ability to remove heavy metals from a given sample due to its pores. Therefore, it is feasible to use cactus to remove heavy metal like $\mathrm{Cd}$ and $\mathrm{Pb}$ from water sample since it abundance, low cost and easily biodegradable.

\section{Acknowledgements}

Researcher wants to express his thanks to the college of Natural and computational science, department of chemistry, Arba Minch University and Ezana milling industry (Mekelle) for providing laboratory facilities. They extend their pleasure to Adigrat University, Ethiopia, for financial supports for this study.

\section{REFERENCES}

[1] Alfarra, S. R; Ali, E. N. and Yusoff, M. M. (2014). Removal of Heavy Metals by Natural Adsorbent. Int. J. Biosci. 4, 130-139.

[2] Mudgal, V.; Madaan, N.; Mudgal, A. and Mishra, S. (2010). Effect of Toxic Metals on Human Health. The Open Nutraceuticals Journal, 3, 94-99.

[3] Ndibewu, P.P.; Mnisi, R.L; Mokgalaka, S.N. and McCrindle, R. I. (2011). Heavy Metal Removal in Aqueous Systems Using Moringa oleifera. J. Materials. Scie. Engi. 1, 843-853.

[4] Pragathiswaran, C.; Sibi, S. and Sivanesan, P.(2013). Adsorption of Hexavalent Chromium from Aqueous Solutions by Aloe Vera Leaf. Int. J. Res. Pharma. Chem, 3, 876-880. 
[5] Derbe, T. and Yilma, B. (2015). Spectroscopic Investigation of Metal Level in Aloe Vera Plant, and the Soil Where the Aloe Vera Grows: Arba Minch, Southern Ethiopia. Modern Chemistry.3, 1-8.

[6] Erdem, E.; Karapinar, N. and Donat, R. (2004). The Removal of Heavy Metal Cations by Natural Zeolites. J. Colloid. Interface Sci. 280, 309-314.

[7] Mane, P. C.; Bhosle, A. B.; Jangam, C. M. and Mukate, S. V. (2007). Heavy Metal Removal from Aqueous Solution by Opuntia: A Natural Polyelectrolyte. J. Nat. Prod. Plant Resour, 1, 75-80.

[8] Badr, N.; Fawzy, M. and Khairia, M. (2012). Phytoremediation: An Ecological Solution to Heavy-Metal-Polluted Soil and Evaluation of Plant Removal Ability. World Applied Sciences Journal, 16, 1292-1301.
[9] Fenglian, F. and Wang, b.(2011). Removal of heavy metal ions from wastewaters: A review. Journal of Environmental Management. 92, 407-418.

[10] O. Keskinkan, O. and Lugal Göksu, M. Z. (2007). Assessment of the Dye Removal Capability of Submersed Aquatic Plants in a Laboratory-Scale Wetland System Using Anova. Brazilian Journal of Chemical Engineering. 24, 193 - 202.

[11] Das, B. and Mondal, N. K. (2011).Calcareous Soil as a New Adsorbent to Remove Lead from Aqueous Solution. Univer. J. Environ. Rese. Technol., 1, 515-530.

[12] Gunatilake, S.K. (2015). Methods of Removing Heavy Metals from Industrial Wastewater. Journal of Multidisciplinary Engineering Science Studies. 1, 13-18.

[13] Fox, I. D. (2011). Cactus Mucilage-Assisted Heavy Metal Separation: Design and Implementation. Graduate School Theses and Dissertations, University of South Florida.1-149. 